\title{
KUEPFERIA PRINGLEI (GENTIANACEAE), A NEW SPECIES FROM THE EASTERN HIMALAYA
}

\author{
S. K. DEY \& D. MAITY*
}

\begin{abstract}
A new species of Kuepferia (Gentianaceae), K. pringlei D.Maity \& Sentu K.Dey from north Sikkim, Eastern Himalaya, is described and illustrated. Details of habitat, phenology and conservation status are given, and it is compared to related species. This previously undescribed species is most similar to, but distinct from, Kuepferia leucantha (Harry Sm. ex T.N.Ho \& S.W.Liu) Adr.Favre, known from Bhutan and China.

Keywords. Eastern Himalaya, Gentianaceae, Kuepferia pringlei D.Maity \& Sentu K.Dey sp. nov.
\end{abstract}

\section{INTR ODUCTION}

The genus Kuepferia Adr.Favre (Gentianaceae) was recently established to include the species formerly in Gentiana section Otophora Kusn. (Favre et al., 2014). The species of Kuepferia have reduced plicae, resembling small teeth or auricles on the sides of the corolla lobes, while other genera of subtribe Gentianinae have well-developed plicae. This major morphological difference is largely supported by the available molecular data (Favre et al., 2010, 2014). The same authors also suggested that the species of Kuepferia appear to be more closely related to Metagentiana T.N.Ho \& S.W.Liu, Crawfurdia Wall. and Tripterospermum Blume, than to any of the remaining sections of Gentiana (Favre et al., 2010, 2014).

Kuepferia, with 13 species, is distributed in India, Nepal, Bhutan, China and Myanmar (Clarke, 1883; Garg, 1987; Ho \& Pringle, 1995; Aitken, 1999; Favre et al., 2014). Kuepferia infelix (C.B.Clarke) Adr.Favre [= Gentiana infelix C.B.Clarke] was, until now, the only species recorded in India, being originally described from Sikkim by C. B. Clarke (1883).

On a visit to the Lhonak valley of North Sikkim District in the course of a floristic study of the region, the authors collected a Kuepferia specimen that resembled K. leucantha (Harry Sm. ex T.N.Ho \& S.W.Liu) Adr.Favre mainly by its bifid (rarely trifid), auriculate plicae, but which differed markedly in having triangular calyx lobes instead of distinctly ovate to broadly elliptic calyx lobes, as in $K$. leucantha (Fig. 1C, D \& J). Moreover, the ovary and capsule were significantly smaller (ovary $2-2.5 \times 1-1.5 \mathrm{~mm}$

Taxonomy and Biosystematics Laboratory, Department of Botany, University of Calcutta, 35 Ballygunge Circular Road, Kolkata - 700 019, W.B., India.

* Author for correspondence. E-mail: debmaity@yahoo.com 
vs. 7-10 × 1-1.5 mm; capsule 3.5-4 mm long vs. 11-12 mm long). Detailed literature studies (Clarke, 1883; Garg, 1987; Ubolcholaket, 1987; Ho \& Pringle, 1995; Aitken, 1999; Ho \& Liu, 1993, 2001; Hul, 2003; Favre et al., 2014) and critical analysis of specimens revealed that the Lhonak valley specimen was a new species of Kuepferia. A detailed description, illustration and images of the new species are provided to facilitate its identification. A comparison of this new taxon with Kuepferia leucantha is also provided (Table 1).

\section{Species Description}

\section{Kuepferia pringlei D.Maity \& Sentu K.Dey, sp. nov.}

Closely related to Kuepferia leucantha (Harry Sm. ex T.N.Ho \& S.W.Liu) Adr. Favre but calyx lobes distinctly triangular with acute to acuminate apex; corolla, corolla lobes, corolla tube, plicae, filaments, anthers, ovary, and style smaller; capsules distinctly stalked; capsules and seeds much smaller; seed surface verrucose with longitudinal lines. - Type: Sikkim, above Kalapathar, near lake, 4400 m, 23 vii 2014, Dey \& Maity 21355 (holo CUH; iso CAL). Figs 1, 2.

Perennial herb, 2-4 cm tall; taproot slender, cylindrical, 3-5 cm long. Stems few to many, prostrate to ascending, slender, simple. Leaves: basal rosette leaves few, larger than stem leaves; leaf blades ovate-elliptic or oblong-lanceolate, 4-7 × 2-4 mm, apex acuminate, margin thick-cartilaginous; stem leaves many, \pm crowded, withering towards stem base; petioles fused to tubular sheath to $2 \mathrm{~mm}$ long; leaf blade ellipticovate to oblong-oblanceolate, 3.5-6 × 1-2 mm, apex acute and mucronate, margin entire, thickened, slightly cartilaginous, lower half often papillose, upper half entire and epapillose; upper leaves epapillose. Flowers terminal, solitary, 5-8.5 mm long; pedicels 1-7 mm long, glabrous. Calyx narrowly campanulate, 5-6 $62.5 \mathrm{~mm}$, glabrous; tube $3-4.5 \mathrm{~mm}$; lobes slightly spreading, narrowly triangular, $2-2.5 \times 0.5-0.75 \mathrm{~mm}$, subequal, apex acute to acuminate. Corolla bluish-white, tubular-campanulate, 6-8.2 mm; tube 6-7 mm long; lobes ovate to triangular, 1.5-2 $\times 1-1.5 \mathrm{~mm}$, apex acute; plicae auriculate, attached to one side of corolla lobe, ovate-triangular, $1-1.7 \times$ $1 \mathrm{~mm}, 2$-cleft; lobes unequal; larger one rarely with emarginate apex; acute to acuminate. Stamens inserted near middle of corolla tube, one rarely larger; filaments 2-3 mm, much dilated at base; anthers c. $0.5 \mathrm{~mm}$; ovarian stipe $1-2.5 \mathrm{~mm}$ long. Ovary narrowly ellipsoid, 2-2.5 × 1-1.5 mm; style $0.5-1 \mathrm{~mm}$; stigma lobes oblong, c. $1 \mathrm{~mm}$, recurved; capsules clavate, c.3.5-4 $\times 2 \mathrm{~mm}$, slightly compressed, on 2-3 mm long stipe, included; dorsal suture keeled at base; ventral suture narrowly winged. Seeds many, angular, oblong-ellipsoid, c. $0.7-0.8 \times 0.3-0.4 \mathrm{~mm}$, base truncate, slightly tapered to the top, surface with verrucose, longitudinal lines, brownish.

Distribution. Endemic in the type locality, Sikkim.

Habitat. On grassy slopes, moss-covered rocks, in moist places, in open alpine meadow, 4300-4500 m. 
T A в L E 1. Comparison of selected morphological characters of Kuepferia pringlei D.Maity \& Sentu K.Dey and K. leucantha (Harry Sm. ex T.N.Ho \& S.W.Liu) Adr.Favre

\begin{tabular}{|c|c|c|}
\hline Character & K. pringlei D.Maity \& Sentu K.Dey & K. leucantha (Harry Sm. ex T.N.Ho \& S.W.Liu) Adr.Favre \\
\hline $\begin{array}{l}\text { Basal rosette leaves } \\
\text { - Occurrence } \\
\text { - Shape } \\
\text { - Size }\end{array}$ & $\begin{array}{l}\text { Always present } \\
\text { Ovate-elliptic or oblong-lanceolate } \\
4-7 \times 2-4 \mathrm{~mm}\end{array}$ & $\begin{array}{l}\text { Often absent } \\
\text { Triangular } \\
2-5 \times 1-3 \mathrm{~mm}\end{array}$ \\
\hline Pedicel & $1-7 \mathrm{~mm}$ long & Absent \\
\hline $\begin{array}{l}\text { Calyx } \\
\text { - Tube } \\
\text { - Lobe, shape } \\
\text { - Lobe, size } \\
\text { - Lobe, apex }\end{array}$ & $\begin{array}{l}3-4.5 \mathrm{~mm} \text { long } \\
\text { Narrowly triangular, subequal } \\
2-2.5 \times 0.5-0.75 \mathrm{~mm} \\
\text { Acute to acuminate }\end{array}$ & $\begin{array}{l}(4-) 5-6 \mathrm{~mm} \text { long } \\
\text { Ovate, broadly elliptic or spathulate, unequal } \\
3-4 \times(1-) 2-2.5 \mathrm{~mm} \\
\text { Acute, obtuse or acuminate and mucronate }\end{array}$ \\
\hline $\begin{array}{l}\text { Corolla } \\
\text { - Colour } \\
\text { - Size } \\
\text { - Tube } \\
\text { - Lobe, shape } \\
\text { - Lobe, size } \\
\text { - Lobe, apex }\end{array}$ & $\begin{array}{l}\text { Bluish-white } \\
6-8.2 \mathrm{~mm} \text { long } \\
6-7 \mathrm{~mm} \text { long } \\
\text { Ovate to triangular } \\
1.5-2 \times 1-1.5 \mathrm{~mm} \\
\text { Acute }\end{array}$ & $\begin{array}{l}\text { White or pale yellow-white } \\
13-15 \mathrm{~mm} \text { long } \\
9-10(-14) \mathrm{mm} \text { long } \\
\text { Ovate to elliptic-ovate } \\
(2-) 4-5 \times 3-4 \mathrm{~mm} \\
\text { Obtuse }\end{array}$ \\
\hline $\begin{array}{l}\text { Plicae } \\
\text { - Shape and nature }\end{array}$ & $\begin{array}{l}\text { Ovate-triangular, 2-cleft, unequal; larger rarely with } \\
\text { emarginated and acute or acuminate apex; acuminate }\end{array}$ & Triangular, 2-cleft \\
\hline - Size & $1-1.7 \mathrm{~mm}$ long & $(1-) 2-2.5 \mathrm{~mm}$ long \\
\hline Filaments & $2-3 \mathrm{~mm}$ & $6-8 \mathrm{~mm}$ \\
\hline Anthers & c. $0.5 \mathrm{~mm}$ & $1.5-2 \mathrm{~mm}$ \\
\hline Stipe (flowering) & $1-2.5 \mathrm{~mm}$ long & $0-2 \mathrm{~mm}$ long \\
\hline
\end{tabular}


TABLE 1. (Cont'd)

\begin{tabular}{lll}
\hline \hline Character & K. pringlei D.Maity \& Sentu K.Dey & K. leucantha (Harry Sm. ex T.N.Ho \& S.W.Liu) Adr.Favre \\
\hline $\begin{array}{l}\text { Ovary } \\
\text { - Shape }\end{array}$ & Narrowly ellipsoid & \\
- Size & $2-2.5 \times 1-1.5 \mathrm{~mm}$ & Ellipsoid \\
Style & $0.5-1 \mathrm{~mm}$ long & $7-10 \times 1-1.5 \mathrm{~mm}$ \\
Capsule & & $1-2.5 \mathrm{~mm}$ long \\
- Stalked/sessile & Stalked & \\
- Shape & Clavate, slightly compressed & Sessile \\
- Size & $3.5-4 \times 2 \mathrm{~mm}$ & Ellipsoid \\
Seed & & $11-12 \times 1.5-2 \mathrm{~mm}$ \\
- Shape & Angular, ellipsoid-oblongoid, slightly tapered towards top & \\
- Size & $0.7-0.8 \times 0.3-0.4$ mm & Ellipsoid or oblongoid \\
- Seed coat & Verrucose with longitudinal lines & $1-1.2 \times 0.4 \mathrm{~mm}$ \\
\hline \hline
\end{tabular}



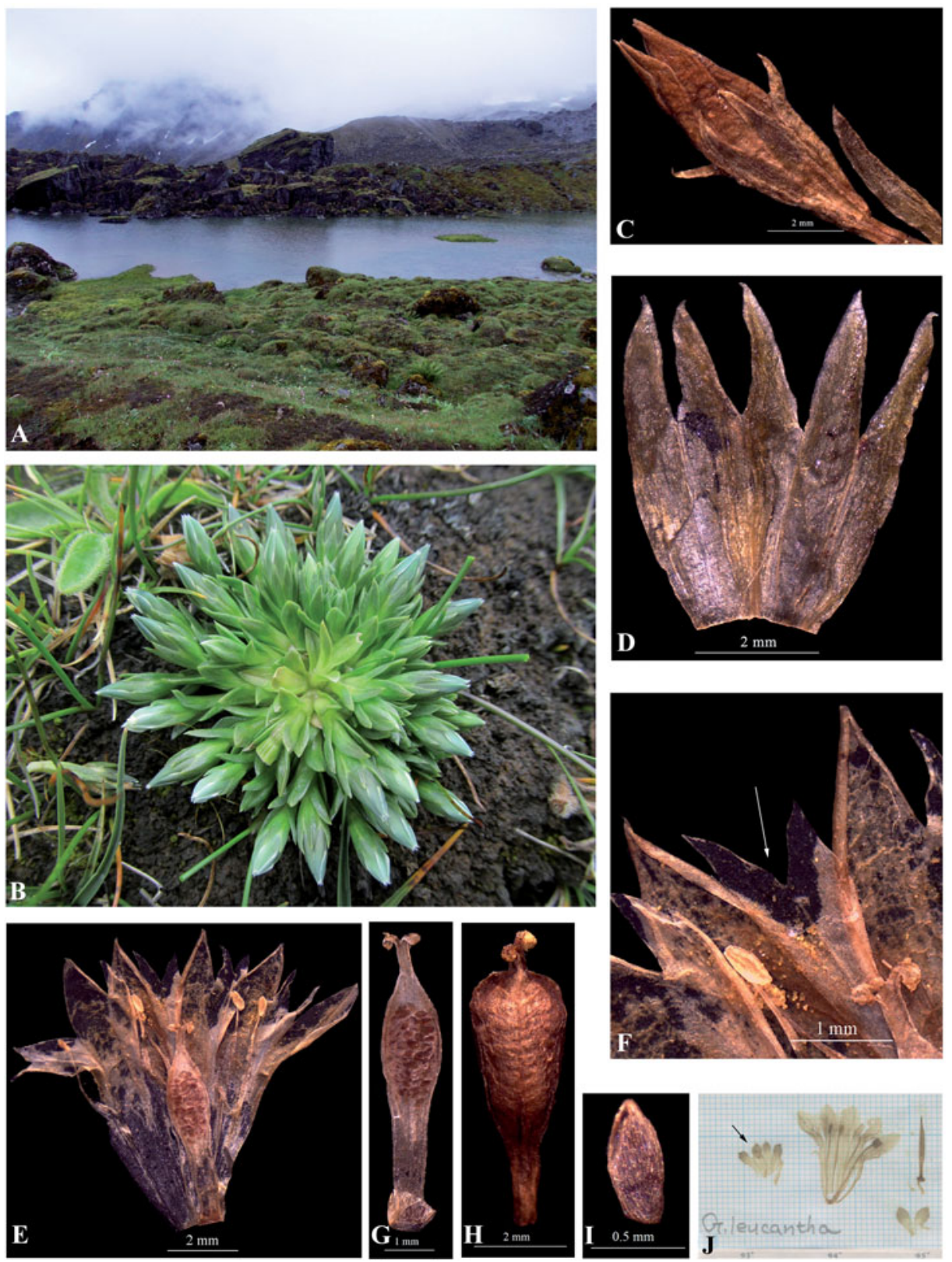

FIG. 1. A-I. Kuepferia pringlei D.Maity \& Sentu K.Dey: A, habitat; B, habit [Dey \& Maity 21386 - CUH]; C, flower (after anthesis); D, calyx split open (ventral face); E, opened corolla with stamens and gynoecium (ventral face); F, two-cleft plicae (marked with arrow); G, gynoecium; H, capsule; I, seed [Dey \& Maity 21355 - CUH]. J, Kuepferia leucantha (Harry Sm. ex T.N.Ho \& S.W.Liu) Adr.Favre: floral parts (note ovate to broadly elliptic calyx lobes marked with arrow) [from Ludlow, Sherriff \& Taylor 5934 (BM), accessed via Global Plants on JSTOR, http://plants.jstor.org/specimen/bm000947152]. 


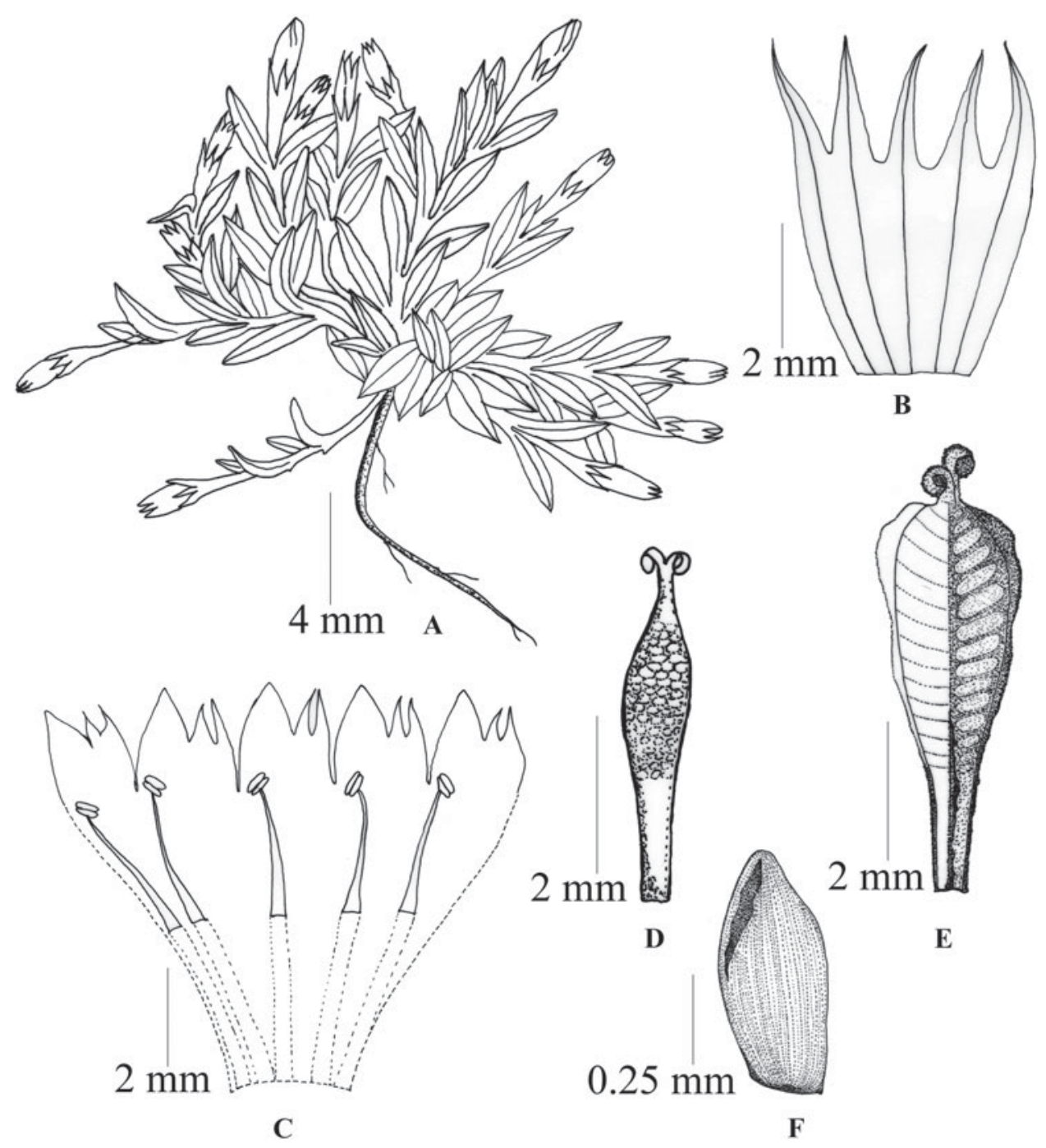

FIG. 2. Kuepferia pringlei D.Maity \& Sentu K.Dey: A, habit; B, opened calyx (ventral face); C, opened corolla showing stamens (ventral face); D, gynoecium; E, capsule; F, seed (from Dey \& Maity 21355 - holotype).

Phenology. Flowering: June-August; fruiting: July-September.

Proposed IUCN conservation status. Critically Endangered (CR). The species is known from a single mountain range in a very restricted area of the Lhonak valley. The type specimen was collected from a population of some eight mature individuals which covered an area of less than $0.5 \mathrm{sq}$. $\mathrm{km}$. After a detailed search of the area around the type locality, along the trekking path between Kalapathar and Muguthang, two more populations were discovered. In total 20-22 individuals were observed in these three 
populations. In view of the very low number of individuals known, the species should be considered Critically Endangered (CR D) (IUCN Standards and Petitions Subcommittee, 2014). The habitat of the species is along the boundary of the Kanchenjunga Biosphere Reserve, Sikkim. Some threats to the habitat are associated with the army camp at Muguthang. Yaks and army personnel carrying military goods and equipment use the footpath along which the plants are found. Conservation measures should be taken to save this new species.

Etymology. The specific epithet honours Dr James S. Pringle, Plant Taxonomist, Royal Botanical Garden, Hamilton, Ontario, the authority on New World Gentiana, from whom the second author received the most generous help regarding the new species.

Additional specimens examined. InDIA. Sikkim, between Kalapathar and Lhonak La (Shiv Mandir), 4500 m, 23 vii 2014, Dey \& Maity 21386 (CUH); below Lhonak La, near lake, 4300 m, 26 vii 2014, Dey \& Maity 21496 (CUH).

Note. Kuepferia pringlei brings the number of species recognised in the genus to 13 , and the number of Indian species to two.

\section{ACKNOWLEDGEMENTS}

We thank the Science \& Engineering Research Board, Govt. of India for financial assistance to our research programme, and the Department of Forests, Environment and Wildlife Management, Govt. of Sikkim, Home Department, Govt. of Sikkim, Superintendent of Police, Gangtok and 17th Mtn. Division, Indian Army for permitting and supporting our field visit. We also thank Mr S. Chakraborty and Mr Guru Lachenpa, who helped us in the field. D.M. is greatly indebted to Dr James S. Pringle (HAM) and Dr A. Favre (LZ) for their valuable suggestions, to Prof. K. N. Gandhi (GH) for his suggestion of the specific epithet, and to Dr Jian-Wen Zhang, Kunming Institute of Botany for his help.

\section{REFERENCES}

Aitken, E. (1999). Gentianaceae. In: Long, D. G. (ed.) Flora of Bhutan, Vol. 2(2), pp. 632-656. Edinburgh: Royal Botanic Garden Edinburgh.

Clarke, C. B. (1883). Gentianaceae. In: Hooker, J. D. (ed.) The Flora of British India, Vol. 4, pp. 108-119. London: L. Reeve \& Co.

Favre, A., Yuan, Y. M., Kuepfer, P. \& Alvarez, N. (2010). Phylogeny of subtribe Gentianinae (Gentianaceae): Biogeographic inferences despite limitations in temporal calibration points. Taxon 59: 1701-1711.

Favre, A., Matuszak, S., Sun, H., Liu, E., Yuan, Y. M.\& Muellner-Riehl, A. N. (2014). Two new genera of Gentianinae (Gentianaceae): Sinogentiana and Kuepferia supported by molecular phylogenetic evidence. Taxon 63(2): 342-354.

GAR G, S. (1987). Gentianaceae of the North West Himalaya (A Revision), pp. 80-122.

New Delhi: Today \& Tomorrow's Printers and Publishers. 
Ho, T. N. \& LiU, S. W. (1993). New taxa of Gentiana (Gentianaceae) from Western China and the Himalayan region. Bull. Nat. Hist. Mus. London (Bot.) 23(2): 55-59.

Ho, T. N. \& Liu, S. W. (2001). A Worldwide Monograph of Gentiana. Beijing: Science Press.

Ho, T. N. \& Pringle, J. S. (1995). Gentianaceae. In: Wu, Z. Y. \& Raven, P. H. (eds) Flora of China (Gentianaceae through Boraginaceae), Vol. 16, pp. 15-97. Beijing: Science Press, and St Louis: Missouri Botanical Garden Press.

Hul, S. (2003). Gentianaceae. In: Flore du Cambodge, du Laos et du Vietnam, Vol. 31. Paris: Muséum national d'histoire naturelle.

IUCN Standards and Petitions Subcommittee (2014). Guidelines for Using the IUCN Red List Categories and Criteria. Version 11. Prepared by the Standards and Petitions Subcommittee. Downloadable from www.iucnredlist.org/documents/ RedListGuidelines.pdf

U воlchola ket, A. (1987). Gentianaceae. In: Flora of Thailand, Vol. 5(1), pp. 72-92. Bangkok: The Forest Herbarium, Royal Forest Department.

Received 26 November 2014; accepted for publication 16 June 2015 